\title{
DO THE DEAD ENLIGHTEN THE LIVING IN UNDERSTANDING ANATOMY?
}

\section{Deepa Somanath ${ }^{1}$, Sudha Ramalingam $* 2$.}

${ }^{1,{ }^{*} 2}$ Department of Anatomy, Sri Manakula Vinayagar Medical College and Hospital, Puducherry, India.

\section{ABSTRACT}

Background: Cadaveric dissection is a traditional method to acquire the anatomical knowledge. Even though the advancement of multimedia and prosected specimens are changing the attitude of the students towards the replacement of dissection.

Purpose of the study: The aim of the study was to assess the attitude of students toward dissection, identifying the factors preventing them from learning and to obtain the suggestions for the improvement of learning in the dissection hall.

Materials and methods: It was a questionnaire based study which involved 140 students of first year undergraduates conducted at Sri Manakula Vinayagar Medical College and Hospital, Pondicherry.

Results: The pre and posttest questionnaires were completed by 140 students. The difference between pre and post test responses regarding the factors distracting the students from learning anatomy in the dissection hall was not statistically significant. Majority of the students opined that hands-on dissection is an important tool to learn gross anatomy even though the results were statistically insignificant.

Conclusion: However different methods of learning anatomy have evolved, the most effective way to understand gross anatomy is cadaveric teaching.

KEY WORDS: Gross anatomy, Cadaver, Dissection, Students' attitude.

Address for Correspondence: Sudha Ramalingam, Tutor, Department of Anatomy, Sri Manakula Vinayagar Medical College and Hospital, Puducherry -605107, India. Phone: 0413-2642016, Fax:0413-2641549 E-Mail: sudhaanatomy@gmail.com

Access this Article online

Quick Response code

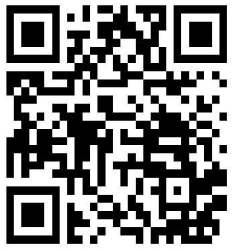

DOI: $10.16965 /$ ijar.2019.144

Journal Information

International Journal of Anatomy and Research

ICV for 2016 ISSN (E) 2321-4287 | ISSN (P) 2321-8967

90.30

https://www.ijmhr.org/ijar.htm

DOI-Prefix: https://dx.doi.org/10.16965/ijar

\section{Article Information}

Received: 12 Feb 2019

Peer Review: 12 Feb 2019

Revised: None
Accepted: 13 Mar 2019

Published (O): 05 Apr 2019

Published (P): 05 Apr 2019

\section{INTRODUCTION}

Attainment of knowledge in anatomy is significant which enhances the medical students' skill to comprehend the clinical scenario of the patient and treating the sick effectively [1]. It lays the basic foundation in medical curriculum. Cadaveric dissection is a traditional method adopted by many medical colleges globally. To acquire this knowledge, the students are exposed to cadaver. A chain of questions arise in students' mind when they encounter human cadaver like the source of cadaver, cause and time of death, embalming procedure, period of usage of cadaver etc. As many of them experience this for the first time, it is doubtless that most of them undergo an emotional stress [2] even though it is a matter of debate for the continuation of cadaveric dissection. The distressing factors a student undergo can be fear and smell of cadaver, shock at the sight of death, thoughts about death, intruding with privacy, sacrilege, mutilation and cultural taboo violation [3].

However, it is an area where the young minds 
are triggered to explore with curiosity and enthusiasm to appreciate the three dimensional aspect of the structures of the human body which is an unique experience. It facilitates a deeper involvement of the student in learning, ability to retain the subject as well. It creates a platform to think in a logical manner. The dissected cadaver remains the most attractive means of understanding anatomy and dissection must not be dismissed as obsolete [4].

However there are cultural changes, modern society, altered medical curriculum, the handson dissecting cadaver have endured and continue to evolve as a primary teaching method in anatomy course. This cannot be achieved by prosection and computerized learning tools [5]. Dissection reinforces and elaborates knowledge that is acquired in lectures and tutorials. Student-cadaver-patient encounter is of utmost importance. Dissection hall is the place where the students learn to practise incisions on the cadaver which will enable them to perform the surgeries meticulously on the living human body. However, the cadaveric dissection is being replaced by prosection, interactive multimedia resources, virtual dissection, other technological tools and models $[6,7]$.

Some researchers believe that one can excel in building the knowledge of human anatomy without performing cadaveric dissection [8]. Recently, controversies emerged regarding the ethical issues on the usage of human body as a learning tool in teaching anatomy [9]. Older believed that cadaveric teaching is not only required by undergraduates but also by higher surgical trainees as it is an effective way of learning gross anatomy [10]. On the other hand, the significance of dissection has steadily declined worldwide over the last few decades thanks to the advent of interactive multimedia resources, models, specimens and various ethical issues regarding human tissue as a learning tool. In certain countries, because of the invasion of problem based learning, the cadaveric dissection hours has been reduced due to time constraint, in some cases even removed from the curricula [1].

In a country like India, where dissection still prevails as the most important tool in the field of anatomy, it is important to determine factors preventing the students from acquiring knowledge through this unique learning experience. There are certain factors that stand as hindrance to dissection as the procedure is considered as expensive, time-consuming, hazardous and stressful causing anxiety. Once these factors are identified, steps can be taken to address these issues and provide the students with a better environment for learning anatomy through dissection.

Objectives:

- To assess the attitude of first year pre-clinical students towards cadaver dissection in two phases of the course

- To identify the factors preventing them from learning anatomy through dissection

- To obtain suggestions for improvement of learning anatomy in the dissection hall.

\section{MATERIALS AND METHODS}

Study design: This study is a quantitative investigatory study which was carried out in the Department of Anatomy, Sri Manakula Vinayagar Medical College and Hospital, Pondicherry.

Sample size: The college has an annual intake of 150 students to the first year of pre-clinical sciences. A total number of 140 students participated in the study. All those willing to take part constituted the study population. The study was conducted twice in the same sample population, once at the beginning of the academic year following a few days of exposure to dissection and the next conducted three months later.

Inclusion criteria: First year, pre-clinical students of Sri Manakula Vinayagar Medical College and Hospital, Pondicherry willing to participate in the study.

Exclusion criteria: Students not willing to participate in the study.

Data collection tools: The objectives of the study were explained to the students and consent was taken from the willing participants. A pre-tested, self- administered questionnaire was given, once at the beginning of the academic year following a few days of exposure to dissection and the next three months later $[1,9,11]$. The students had to choose from the 


\section{Attitude of medical students towards dissection- Proforma (Pre and Post Measurement)}

Table:1 $[1,9,11]$ : Kindly give your opinion by marking a tick in the boxes under 'Yes' or 'No' or 'Cannot say'.

\begin{tabular}{|c|c|c|c|c|}
\hline S. No. & Question & Yes & No & $\begin{array}{l}\text { Cannot } \\
\text { Say }\end{array}$ \\
\hline i. & Did you find your first visit to the dissection room exciting? & & & \\
\hline ii. & Were you upset at the beginning of dissection? & & & \\
\hline iii. & Did you feel any emotional shock at initial exposure to cadaver? & & & \\
\hline iv. & If so, whether the shock decreased gradually? & & & \\
\hline v. & Did you have any apprehension to handle the cadaver directly? & & & \\
\hline vi. & $\begin{array}{l}\text { Did you experience anxiety and stress immediately before and } \\
\text { during dissection? }\end{array}$ & & & \\
\hline vii. & Did you prepare mentally for dissection of human cadaver? & & & \\
\hline viii. & $\begin{array}{l}\text { Did you ever think that the cadaver you dissected was once a living } \\
\text { human being like you? }\end{array}$ & & & \\
\hline ix. & If so, did you ever have any sympathy and respect for him/her? & & & \\
\hline $\mathbf{x}$. & $\begin{array}{l}\text { Do you think that you can do better dissection with assistance from } \\
\text { your teacher? }\end{array}$ & & & \\
\hline xi. & $\begin{array}{l}\text { Do you have any prior experience of a dead human body before } \\
\text { entering the dissection room? }\end{array}$ & & & \\
\hline xii. & $\begin{array}{l}\text { If so, whether the prior experience helped you in developing a } \\
\text { better coping mechanism to adjust to cadaver dissection? }\end{array}$ & & & \\
\hline xiii. & $\begin{array}{l}\text { Do you think that dissection enhances the skill of thinking in a } \\
\text { logical manner? }\end{array}$ & & & \\
\hline xiv. & $\begin{array}{l}\text { Do you think that dissection gives the best method for learning } \\
\text { anatomy? }\end{array}$ & & & \\
\hline $\mathbf{x v}$. & $\begin{array}{l}\text { Do you think that cadaver dissection for anatomical learning is } \\
\text { ethically acceptable? }\end{array}$ & & & \\
\hline xvi. & $\begin{array}{l}\text { Do you think that cadaver dissection technique can be replaced by } \\
\text { plastic models, computer assisted training programme etc.? }\end{array}$ & & & \\
\hline xvii. & $\begin{array}{l}\text { Do you think that actual hands- on training on cadaver dissection } \\
\text { gives better results than demonstration of prosected specimens? }\end{array}$ & & & \\
\hline xviii. & $\begin{array}{l}\text { Do you think that cadaver dissection is still considered important } \\
\text { and indispensable to Anatomy learning? }\end{array}$ & & & \\
\hline
\end{tabular}

given options of 'yes', 'no' and 'cannot say' for the listed questions. They were also asked to give suggestions, if any, for the improvement of learning in the dissection hall.

Ethical approval: This study was approved by Institutional Human Ethics Committee, Sri Manakula Vinayagar Medical College and Hospital, Pondicherry (Ref: SMVMCHEC/DAO/ Al/398/2014).

Table:2 [1,9,11]: Q: Do you feel any of the following factors distract you or make you uncomfortable in the dissection hall?

\begin{tabular}{|c|l|c|c|}
\hline S. No. & \multicolumn{1}{|c|}{ Factors } & Yes & No \\
\hline i. & Smell of the dissection hall & & \\
\hline ii. & Irritation to the eyes & & \\
\hline iii. & Fear of the cadaver & & \\
\hline iv. & Fear of infection & & \\
\hline v. & Lack of motivation/ interest & & \\
\hline
\end{tabular}

Int J Anat Res 2019, 7(2.1):6462-67. ISSN 2321-4287
Q: Please give suggestions that may help improve the anatomy learning in this college.

Data analysis: Data was entered and analyzed using Epi-info software version (3.4.3). Paired $\mathrm{t}$ test was applied to appreciate the difference between the responses of students at two given times.

Table 3: showing responses of the students regarding learning anatomy through cadaveric dissection.

\begin{tabular}{|l|c|c|c|}
\hline \multicolumn{1}{|c|}{ Responses of the students } & Mean & SD & P value \\
\hline Pretest - "yes" responses & 76.22 & 45.6 & \multirow{2}{*}{0.7401} \\
\hline Posttest - "yes" responses & 81.4 & 47.3 & \\
\hline Pretest - "no" responses & 53 & 43.9 & \multirow{2}{*}{0.917} \\
\hline Posttest - "no" responses & 51.4 & 47.5 & \\
\hline Pre test - "can't say" responses & 9.7 & 8.8 & \multirow{2}{*}{$0.0407^{*}$} \\
\hline Posttest - "can't say" responses & 7.2 & 5.6 & \\
\hline
\end{tabular}


Table 4: showing responses of the students regarding the factors that distract them from learning anatomy in dissection hall.

\begin{tabular}{|l|c|c|c|}
\hline \multicolumn{4}{|c|}{ Distracting factors } \\
\cline { 1 - 4 } \multicolumn{1}{|c|}{ Response } & Mean & SD & P value \\
\hline Pretest - "yes" responses & 30 & 23.7 & \multirow{2}{*}{0.7173} \\
\hline Posttest - "yes" responses & 27.2 & 22.3 & \\
\hline Pretest - "no" responses & 40 & 23.4 & \multirow{2}{*}{0.8592} \\
\hline Posttest - "no" responses & 42.8 & 22.4 & \\
\hline
\end{tabular}

$* p<0.05$ is statistically significant

\section{DISCUSSION}

The pre and posttest questionnaires were completed by 140 students. No statistically significant difference was found in "Yes" response and "No" response for the items displayed in the questionnaire (Table:1). But "cannot say" response was statistically significant (Table:1). The difference between pre and post test responses regarding the factors distracting the students from learning anatomy in the dissection hall was not statistically significant (Table:2).

Even with the advancement of technology, cadaveric dissection is considered as the best tool to learn gross anatomy. The anatomical knowledge of the students is enhanced by gross dissection method [12]. Prosected specimens used in gross anatomy labs are found to be convenient as they are already dissected and they do not impart the fear of the sight or smell of cadaver. Traditional dissection is much preferred over the prosection-based learning [1]. No statistically significant difference was found in "Yes" response and "No" response for the items displayed in the questionnaire of pre and posttest (Table:1). But "cannot say" response was statistically significant (Table:1). We speculate that the above results might be attributed to the reasons such as the students were not clear regarding the attainment of gross anatomy knowledge through cadaveric dissection. The initial three months of course duration should be taken for the acclimatization of the students to the environment of the dissection lab because anatomical terms are in Greek and Latin and understanding the structures by doing dissection and appreciating them might have been too difficult at the initial period. If time given was sufficient, their interpretation would have been different.
Regarding the distracting factors, no significant difference was found between pre and posttests. Odour of cadaver, fear of infection, irritation of eyes persisted throughout the duration of the study [13]. The above result correlated with a study conducted by Cahill and Ettarh who stated that before and after the first class, the intensity of apprehension and nausea remained same even during the entire period of study [8]. The enormous content of the subject might shift the students from the emotional state to the practical scenario by gaining exposure and experience in working with the cadavers. Acquired knowledge and experience changed the attitude and opinion of students during the study course [2]. In the initial period of exposure to cadaver, the anxiety experienced by the students can be a hindrance to the learning because dead bodies are encountered for the first time in their lives.

As time advances, the level of stress decreases as they get adapted to the dissection room. In our study, the level of anxiety was sustained throughout the period. In contradiction to our statement, in a study by Bob et al stated that the stress level was increased from before the first cadaveric dissection to after one month of dissection, but after a month the anxiety level increased [14]. This might be due to insufficient time for habituation. Alt-Epping reported that $89.1 \%$ of the students experienced uneasiness but $61.7 \%$ felt some kind of apprehension [15]. One-third of them did not feel anxiety at all. This may be due to the mental preparation of the students towards the course. Cahill K observed his students to be less stressed towards the end of study.

When students were asked to give suggestions to improve gross anatomy learning in the dissection hall, out of 140, 92 students responded. Most of them reported cadaveric dissection as the most important, useful and easy method to learn anatomy as they learn by dissecting layer by layer and get oriented to the structures very well unlike prosected specimens which are already dissected and give less scope for orientation and relations between structures. They also suggested that less number of students to be allowed in a group, each and every one to be given a chance to dissect, to increase the dissection hours. Few students 
opined, the smell of dissecting room, fear of infection and eye irritation to be taken care.

Cho and Hwang documented that more than half of the total students felt that anatomy course was helpful for the clinical practice because the anatomy content correlated with the clinical subjects, if not will not be considered [16]. Majority of the students accepted hands-on cadaveric dissection gave better results than prosected specimens [1]. Dissection classes with clinical input would enhance the deep anatomical knowledge and skills [17]. Dissection learning aided by surgeons would help the students for construction and retainment of knowledge [18]. Most of the students appreciated working with cadaver and considered it as a valuable tool for learning $[19,8]$. Rehkamper suggested a method called 'free dissection' which provokes self-competency in the students and keep them self-organised [20].

In order to deal with the environmental and emotional stress in the dissection room, a predissection course should be conducted which comprises of information regarding death and dying, treating the cadaver in a respectful way, methods to cope up with the anxiety and uncomfortable feelings. The fear of infection can be dealt by educating them about embalming. Chiou et al explained the ceremonial procedures which involve relatives of body donor, students and faculty of anatomy department to share the life time memories of the silent mentor and this would bring about a sense of respect and gratefulness for the cadaver [21]. Dissection class experiences and coping techniques can influence the doctor-patient relationship positively [22].

\section{CONCLUSION}

In this study we could conclude that the level of anxiety in the students remained the same throughout showing no difference between the pre and post test results and they could not say that the cadaveric dissection is useful. However the majority of the students opined that cadaveric dissection as the most effective tool in anatomy learning and most of the students perceived the dissection as a resource for learning the three-dimensional anatomical structures. The probable reasons for such a response may be attributed to the time constraint for adaptation and early examination of their attitudes after a short time exposure. In order to address the issues raised by the students, steps have to be taken to deliver a pre-dissection course, increase the availability of cadavers, to allot less number of people in a group and prolong the time allotted for dissection.

\section{ACKNOWLEDGEMENTS}

The authors would like to thank the students of SMVMCH for their participation.

\section{Conflicts of Interests: None}

\section{REFERENCES}

[1]. Ali A, Khan Z N, Konczalik W, Coughlin P, El Sayed S. The perception of anatomy teaching among UK medical student 2015; 97:9;397-400 DOI: 10.1308/ rcsbull.2015.397.

[2]. Bernhardt V, Rothkötter H J, Kasten E. Psychological stress in first year medical students in response to the dissection of a human corpse. GMS Z Med Ausbild 2012;29(1):Doc12.

[3]. Hancock D, Williams M, Taylor A, Dawson B. Impact of cadaver dissection on medical students. New Zealand journal of Psychology 2004;33(1).

[4]. Hasan T. Is dissection humane? J Med Ethics Hist Med 2011;4:4.

[5]. Agnihotri G, Sagoo M G. Reactions of first year Indian medical students to the dissection hall experience. National Journal of Integrated Research in Medicine 2010;1(4)

[6]. Naz S, Nazir G, IramS, Mohammad M, Umair, Qari I H, Mohammad S. J Ayub Med Coll Abbottabad 2011;23(3).

[7]. Karau P B, Wamachi A, Ndede K, Mwamisi J, Ndege $P$. Perception to cadaver dissection and views on Anatomy as a subject between two pioneer cohorts in a kenyan medical school. Anatomy journal of Africa 2014;3(2):318-323.

[8]. Cahill K C, Ettarh R R. Attitudes to Anatomy Dissection in an Irish Medical School. Clin Anat 2009;22:386-391.

[9]. Izunya A M, Oaikhena G A, Nwaopara A O. Attitudes to Cadaver Dissection in a Nigerian Medical School. Asian Journal of Medical Sciences 2010;2(3):89-94.

[10]. Older J. Anatomy: a must for teaching the next generation. Surgeon 2004;2:79-90.

[11]. Oyeyipo I P, Falana B A. Attitude of preclinical students to cadaver dissection in a south west Nigerian medical school. International journal of tropical medicine 2012;7(1): 1-5.

[12]. Winkelmann A. Anatomical dissection as a teaching method in medical school: a review of the evidence Medical Education 2007;41:15-22.

[13]. Getachew D. Reaction of medical students to experiences in dissection room. Ethiop J Health Sci $2014 ; 20(4)$. 
[14]. Bob M H, Popescu C A, Suciu S M, Buzoianu A D. First year medical students' attitude toward anatomical corpse dissection and its relationship with their personality. Rom J Morphol Embryol 2015;56(1):321-324.

[15]. Alt-Epping B, Lohse C, Viebahn C, Steinbüchel N V, Benze G, Nauck F. On death and dying - an exploratory and evaluative study of a reflective, interdisciplinary course element in undergraduate anatomy teaching. BMC Medical Education 2014;14:15.

[16]. Cho M J and Hwang Y. Students' perception of anatomy education at a Korean medical college with respect to time and contents. Anat Cell Biol 2013;46(2):157-162

[17]. H E, Valter K, Webb A L.Current Integration of Dissection in Medical Education in Australia and New Zealand: Challenges and Successes. Anat Sci Educ 2015; DOI 10.1002/ase.1559.

[18]. Burgess A, Ramsey Stewart G. Anatomy by whole body dissection: a focus group study of students' learning experience 2015;6:533-37. https:// dx.doi.org/10.2147/AMEP.S86583.
[19]. Khan M H, Mirza T M. Physical and psychological effects of cadaveric dissection on undergraduate medical students. JPMA 2013;63:831.

[20]. Rehkämper G. Human Dissection in Medical Education: More than Just Anatomy. GMS Journal for Medical Education 2016;33(5).

[21]. Chiou R J, Tsai P F, Han D H. Effects of a "silent mentor" initiation ceremony and dissection on medical students' humanity and learning. BMC Res Notes 2017;10:483.

[22]. Sándor I, Birkás E, Gyõrffy z. The effects of dissection-room experiences and related coping strategies among Hungarian medical students. BMC Medical Education 2015;15:73.

How to cite this article:

Deepa Somanath, Sudha Ramalingam. DO THE DEAD ENLIGHTEN

THE LIVING IN UNDERSTANDING ANATOMY?. Int J Anat Res 2019;7(2.1):6462-6467. DOI: 10.16965/ijar.2019.144 